\title{
FGFR1/ZMYM2 Fusion Gene
}

National Cancer Institute

\section{Source}

National Cancer Institute. FGFR1/ZMYM2 Fusion Gene. NCI Thesaurus. Code C99714.

A fusion gene that results from a chromosomal translocation $\mathrm{t}(8 ; 13)(\mathrm{p} 11 ; \mathrm{q} 12)$ which fuses the first 8 exons of the FGFR1 gene to exon 18 of the ZYZM2 gene. This rearrangement is associated with 8p11 myeloproliferative syndrome. 